Canadian

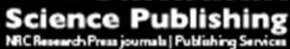

Applied Physiology, Nutrition, and Metabolism Physiologie appliquée, nutrition et métabolisme

\title{
Longitudinal trends in use of dietary supplements by US Army personnel differ from those of civilians
}

\begin{tabular}{|r|l|}
\hline Journal: & Applied Physiology, Nutrition, and Metabolism \\
\hline Manuscript ID & apnm-2016-0296.R1 \\
\hline Manuscript Type: & Article \\
\hline Date Submitted by the Author: & 27-Jun-2016 \\
\hline Complete List of Authors: & $\begin{array}{l}\text { Austin, Krista; US Army Research Institute of Environmental Medicine, } \\
\text { Military Nutrition Division; Henry M. Jackson Foundation } \\
\text { Price, Lori; Tufts Medical Center } \\
\text { McGraw, Susan; US Army Research Institute of Environmental Medicine, } \\
\text { Military Nutrition Division } \\
\text { McLellan, Tom; TM McLellan Research Inc., } \\
\text { Lieberman, Harris; US Army Research Institute of Environmental Medicine, } \\
\text { Military Nutrition Division }\end{array}$ \\
\hline Keyword: & \begin{tabular}{l} 
protein, vitamin, mineral, Armed Forces, exercise \\
\hline
\end{tabular} \\
\hline
\end{tabular}




\section{Longitudinal trends in use of dietary supplements by US Army personnel differ from those of civilians}

Krista G. Austin ${ }^{1,2}$, Lori Lyn Price ${ }^{3}$, Susan M. McGraw ${ }^{1}$, Tom M. McLellan ${ }^{4}$ and Harris R. Lieberman $^{1}$

${ }^{1}$ Military Nutrition Division, US Army Research Institute of Environmental Medicine, Natick, MA

${ }^{2}$ Henry Jackson Foundation, Bethesda, MD 20817

3 Tufts Medical Center, Tufts University, Boston, MA

${ }^{4}$ TM McLellan Research Inc., Stouffville, ON L4A8A7

Address correspondence and request for reprints to:

Dr. Harris R. Lieberman

Military Nutrition Division

US Army Research Institute of Environmental Medicine

Natick, MA 01760

Phone: (508) 233-4856

Fax: (508) 233-5854

E-mail: harris.r.lieberman.civ@mail.mil

Running Title: Longitudinal Trends in Dietary Supplement Use in US Army Personnel 


\begin{abstract}
Prevalence and patterns of dietary supplement (DS) use by U.S. Army Soldiers differ from the civilian population. Longitudinal trends in use of DS by civilians have been examined, but are unavailable in subpopulations such as military service members. The present study examined longitudinal changes in DS use by Soldiers. A standardized questionnaire on DS use was administered in 2006-07 ( $\mathrm{n}=989)$ and 2010-11 $(\mathrm{n}=1196)$ to a convenience sample of active duty Soldiers. Data were weighted for total population demographics of age, sex, and rank. Regular use of DS by Soldiers increased significantly $(56 \% \pm 1.6$ vs. $64 \% \pm 1.7 ; \mathrm{p} \leq .001)$ over the 4 years primarily due to increase DS use among the youngest $18-24$ year old Soldiers $(43.0 \% \pm 2.5$ vs $62.3 \% \pm 2.4 ; \mathrm{p} \leq .01)$. Protein $(22 \% \pm 1.4$ vs. $26 \% \pm 1.5 ; \mathrm{p} \leq .001)$ and combination $(10.0 \% \pm$ 1.0 vs. $24 \% \pm 1.4 ; \mathrm{p} \leq .001)$ product consumption also increased over the 4 years. Individual vitamin and mineral use, including iron, magnesium, selenium, Vitamins A, B6, B12, and D, also significantly increased $(\mathrm{p} \leq .05)$. In addition, expenditures on DS by Soldiers increased over time $(\mathrm{p}<.01)$. Use of DS by Soldiers significantly increased over the time period examined. Reasons reported by Soldiers for DS use suggest use increased to meet the occupational demands of military service. Educational interventions to minimize inappropriate use of DS by Soldiers are necessary to reduce adverse events resulting from unnecessary use of DS and wasted financial resources on unproven remedies.
\end{abstract}

Key Words: protein, vitamin, mineral, Armed Forces, military, exercise 


\section{Introduction}

Cross sectional studies of dietary supplement (DS) use by the U.S. adult civilian population have reported a slight decrease in use between 2003-2006 and 2007-2010 (53\% vs. 49\%, respectively) (Bailey et al. 2011; Bailey et al. 2013). Multiple reports have documented a greater prevalence of DS use among active duty military personnel than the general U.S. civilian population (Department of Defense 2005; Lieberman et al. 2010; Austin et al. 2015; Austin et al. 2016c). In addition, patterns and reasons for DS use by Soldiers differ substantially from the civilian population with Soldiers reporting much greater use of protein supplements and combination products as they believe these products will improve muscle strength, enhance performance and facilitate weight loss (Lieberman et al. 2010; Jacobson et al. 2012). Despite differences in prevalence and patterns of DS use, information regarding longitudinal changes in prevalence of DS use among certain occupational subgroups such as the military is not available as this information is not typically included in national health surveillance studies. In 2008 , the Institute of Medicine (IOM) Committee on Dietary Supplement Use stated there was a critical requirement to regularly survey military populations to improve detection of harmful DSs entering the market and establish interventions that minimize use of potentially harmful DSs by service members (IOM 2008).

Extensive use of DSs by Soldiers has raised concern about the short and long term safety and efficacy of many DSs and limited regulation of these products by the Food and Drug Administration (FDA) (Denham 2011; Pasiakos et al. 2013; Deuster and Lieberman 2015). Due to limited oversight of DSs entering the market place, dangerous DSs have reached service members and compromised their health and performance (Eliason et al. 2012; Austin et al. 2016b). 
Based on previous reports suggesting greater use of DSs among active duty Soldiers and the need for interventions to prevent adverse events from DS use among this population, we readministered a survey previously administered to US active duty Army Soldiers to assess changes in prevalence, patterns of use and reasons for use of DSs (Lieberman et al. 2010). In addition, we discuss changes in use of DSs by active duty Soldiers compared to changes in DS use by the general civilian population over a similar period of time.

\section{Methods}

\section{Participants}

This study was approved by the Human Use Review Committee of the U.S. Army Research Institute of Environmental Medicine. From 2006-07 and from 2010-11, data were collected from 989 and 1,207 active duty Soldiers, respectively, to ascertain prevalence and patterns of DS use using a standardized survey tool, the Dietary Supplement and Caffeine Intake Survey of U.S. Army Active Duty Personnel (Lieberman et al. 2010). The data obtained for the 2006-2007 study were collected at 11 locations (9 U.S. installations and 2 overseas sites). In 2010-2011, 12 Army (10 U.S. installations and 2 overseas sites) bases were surveyed. Active duty Army personnel were eligible to complete the survey (504,422 Army personnel as of January 1, 2007; 533,107 Army personnel as of November 30, 2011). We did not survey Soldiers enrolled in Basic Combat Training or Advanced Individual Training because they are prohibited from consuming DSs. Users and non-users of DSs were included in the samples. Survey sites were chosen based on size, the diversity of the population present and the availability of healthcare professionals to assist with survey administration. No incentives were offered to participants for completion of the survey. Participants completed the survey after an explanation that all information obtained would remain confidential and that participation was voluntary. 
Investigators adhered to U.S. Army Regulation 70-25 and U.S. Army Medical Research and Materiel Command Regulation 70-25 on the use of volunteers in research (Department of Army 1990).

Survey

Prior to administering the survey, participants were briefed regarding its contents and procedures for correctly completing all questions. The survey consisted of 43 questions on type of DS used, frequency (never, 1 time/month, 1 time/week, $>1$ time/week and daily), reasons for use (general health, enhance performance, improve endurance, increase muscular strength, weight loss, unsure or other) and money spent on DSs. The survey also collected information on demographic and lifestyle factors including age, sex, body mass index (BMI), education, occupation, marital status, tobacco use and participation in aerobic and strength training exercise. Ninety-two individual supplements were listed on the survey including 55 general supplements such as multivitamins, individual vitamins and minerals, antioxidants and 37 specific-named products. Brand name DSs were selected for inclusion on the survey based on then-current patterns of DS purchases at the Army and Air Force Exchange System and General Nutrition Center stores on or near Army installations. Prior to data analyses, individual supplement and supplement types were grouped into the following categories: multivitamin and multimineral, individual vitamins and minerals, protein/amino acid supplements, combination products, herbal supplements, purported steroid analogs and other. Supplements were categorized based on the definitions provided in Table 1. A standardized taxonomy used in national surveys such as National Health and Nutrition and Examination Survey was used to categorize DSs (Bailey et al. 2011). Participants were also queried about the use of sports drinks, bars or gels, and meal replacement beverages based on previous reports indicating they are frequently used by military 
personnel (Lieberman et al. 2010). These nutritional products were analyzed separately, and not reported here, as they are not classified as a DS by the DSHEA of 1994.

\section{Insert Table 1 about here}

\section{Data Analyses}

Completed surveys were scanned using ScanTools Plus with ScanFlex (version 6.301; Scantron Corporation, Eagan, MN) and data imported into SPSS (version 20.0; SPSS Inc, Chicago, IL) for conversion to a SAS (version 9.4; SAS Institute, Cary, NC) data file for all statistical analyses. Data were weighted prior to analysis to obtain a sample representative of the overall Army composition as of January 1, 2007 for the study conducted in 2006-07 and as of November 30, 2011 for the study conducted in 2010-11. Weights were based on demographic data, including sex, age and rank, obtained from the Defense Manpower Data Center (www.dmdc.osd.mil/) and the characteristics of survey respondents. The survey weight for each data set was calculated by dividing the number of Army personnel in each cell who were eligible to take the survey by the number in the cell that completed the survey.

Wald chi-square tests were used to assess significant differences in mean percentages among multiple characteristic levels. The proc surveyfreq procedure was used to test differences in reported rates of DS consumption across multiple characteristic levels. A p-value of $<0.05$ was considered statistically significant. Standard errors were estimated using a Taylor series linearization method that incorporated sampling weights. Logistic regression models were used to examine interactions between measures of DS use, time period and demographic characteristics including age, sex, education, marital status, BMI, tobacco use, as well as, aerobic exercise duration and strength training. We adjusted our models for sex, age and rank given the significant relationship of these predictor variables to DS categories of interest (Lieberman et al. 
2010). We considered adjusting for education; however, categorical levels of rank and education variables were highly co-varied and as such, analyses were performed on models adjusted only for age, gender, and rank.

\section{Results}

Longitudinal Differences in Prevalence and Patterns of DS Use

Differences in prevalence and patterns of DS use between 2006-07 and 2010-11 are presented by demographic and lifestyle characteristics in Table 2. Use of any DS at least one time per week ( $\geq 1$ time/wk) in the 6 months prior to the survey significantly increased from $56 \%$ to $64 \%$ between $2006-07$ to $2010-11$ ( $<<0.05)$. Self-reported consumption of protein and amino acid DSs increased from $22 \%$ to $26 \%(\mathrm{p}<0.05)$, combination product use from $10 \%$ to $24 \%(\mathrm{p}<0.01)$ and use of DSs classified as 'other' from $13 \%$ to $17 \%(\mathrm{p}<0.01)$ across survey periods. Prevalence of purported steroid analogs decreased from 2006-07 to 2010-11 (3\% vs 1\%, $\mathrm{p}<0.05)$. Overall prevalence of individual vitamin and mineral use did not significantly increase; however, use of some specific vitamins and minerals (Table 3), including Vitamin D (6\% vs. $10 \%, \mathrm{p}<0.01)$, Vitamin A (6\% vs. 8\%, p<0.05) Vitamin B12 (4\% vs. 6\%, p<0.05), iron (5\% vs. $7 \%, \mathrm{p}<0.05)$ and magnesium (3\% vs. $6 \%, \mathrm{p}<0.05)$ did increase significantly over time. Expenditures on DSs increased significantly between 2006-07 and 2010-11 with a significantly greater percentage of respondents $(25 \%$ vs. $32 \%$, respectively, $\mathrm{p}<0.01)$ reporting expenditures of $\$ 50$ dollars or more every month. With the exception of the use of $1-2$ DSs (31\% vs. 31\%), not using a DS (44\% vs $36 \%)$, or using 3-4 DSs (11\% vs. $14 \%$ ) or 5 or more DSs (14\% vs. 19\%), were significantly different between 2006-07 and 2010-11, respectively.

In the 2010-11 cohort, overall use of any DS was significantly higher among Soldiers reporting a history of deployment $(\mathrm{p}<0.01)$ and use increased among combat arms and combat 
support personnel $(\mathrm{p}<0.05)$ (Table 2$)$. Supplement use was significantly greater among females $(\mathrm{p}<0.05)$, respondents participating in strength training $(\mathrm{p}<0.01)$ and increased proportionately with duration of aerobic exercise completed each week $(\mathrm{p}<0.05)$; however, use of any DS was significantly higher among those reporting a BMI of 25-29.9 $(\mathrm{p}<0.05)$. Use of DSs by Soldiers was not significantly related to age, educational obtainment, rank, marital status or tobacco use as was previously identified in 2006-07. Demographic predictors of DS use for the 2006-07 cohort have been reported previously (Lieberman et al. 2010).

Demographic predictors of types of DS used by Soldiers were similar in 2006-07 and 2010-11 (Lieberman et al. 2010). In the 2010-11 cohort, prevalence of multivitamin and mineral use increased with level of educational obtainment $(\mathrm{p}<0.01)$, a history of deployment $(\mathrm{p}<0.05)$, aerobic exercise duration $(\mathrm{p}<0.05)$ and strength training $(\mathrm{p}<0.01)$. Respondents with a BMI of 18-24.9 or greater than 30 reported an increased use $(p<0.01)$ of multivitamin and minerals. Use of protein and amino acid DSs was significantly greater: 1$)$ among males $(\mathrm{p}<0.01) ; 2)$ younger Soldiers $(p<0.01) ; 3)$ enlisted personnel $(p<0.05) ; 4)$ unmarried Soldiers $(p<0.05) ; 5)$ respondents assigned to combat arms units $(\mathrm{p}<0.01) ; 6)$ smokers $(\mathrm{p}<0.01) ; 7)$ those with a history of deployment $(\mathrm{p}<0.05) ; 8)$ those with a greater number of deployments $(\mathrm{p}<0.05)$; 9$)$ participation in strength training $(\mathrm{p}<0.01)$; and 10) aerobic exercise of longer durations $(\mathrm{p}<0.01)$. However, protein supplement use decreased over time among respondents with a bachelor or graduate degree $(\mathrm{p}<0.01)$. Individual vitamin and mineral use was only greater among female Soldiers $(\mathrm{p}<0.01)$. Combination product use was significantly more prevalent among: 1$)$ males $(\mathrm{p}<0.05)$; 2) younger Soldiers $(\mathrm{p}<0.05) ; 3)$ respondents with a lower level of educational obtainment $(\mathrm{p}<0.05) ; 4)$ enlisted personnel $(\mathrm{p}<0.05) ; 5)$ combat arms and combat support personnel $(\mathrm{p}<0.01) ; 6)$ smokers and former smokers $(\mathrm{p}<0.01) ; 7)$ respondents with a history of deployment 
$(\mathrm{p}<0.01) ; 8)$ a BMI greater than $29.9(\mathrm{p}<0.05) ; 9)$ participation in strength training $(\mathrm{p}<0.01)$; and 10) aerobic exercise duration $(\mathrm{p}<0.01)$. Use of herbal supplements was significantly greater among combat arms and combat support personnel $(\mathrm{p}<0.01)$. Enlisted personnel or those with a military specialization in combat arms $(\mathrm{p}<0.05)$ reported a greater use of purported steroid analogs. Use of dietary supplements classified as 'other' was significantly greater among combat arms and combat support personnel $(\mathrm{p}<0.01)$, and respondents performing strength training $(\mathrm{p}<0.01)$

\section{Insert Tables 2 and 3 about here}

\section{Interaction Analysis of DS Use}

The interaction term of the logistic regression analysis on the 2006-07 vs. 2010-11 data sets was examined to see if some characteristics (such as sex) had a different relationship with DS use over time (Table 4). Significant interactions were found for all supplement types except individual vitamins or mineral and herbal supplements, most commonly with age, rank and number of deployments. No significant interactions were found for supplement type as a function of marital or deployment status. In comparison to 2006-07, use of any DS by Soldiers in 2010-11 significantly increased among 18-24 year old Army personnel (43\% vs. 62\%, $<<0.01)$ but not any other age group. Individuals with some high school $(42 \%$ vs. $59 \%, \mathrm{p}<0.05)$ or some college education $(58 \%$ vs. $66 \%, \mathrm{p}<0.05)$ reported increased supplement use between $2006-07$ and 2010 2011; however, while use of any DS decreased among those reporting having a bachelor/graduate degree (72\% vs. 67\%), it was not significant. Supplement use was greater among respondents of lower enlisted ranks (E1-E4) (43\% vs. 61\%, p<0.01), but was not significantly greater among higher ranking enlisted personnel (E5-E9 rank; 64\% vs. 66\%) or Officers (69\% vs. 67\%). Current users of tobacco products $(49 \%$ vs. $63 \%, \mathrm{p}<0.05)$ reported 
increased use of DSs but prevalence of use by former smokers (63\% vs. $71 \%)$ and respondents who never smoked did not change significantly (61\% vs. $62 \%$ ) from $2006-07$ to $2010-11$. Comparison within demographic categories between 2006-07 and 2010-11 identified increased use of any DS by personnel reporting 1-2 deployments ( $57 \%$ vs. $68 \%$, p $<0.01)$; however, no significant difference was identified by participants reporting no history of deployment (49\% vs. $56 \%$ ), 3-4 deployments ( $71 \%$ vs. $61 \%$ ) or 5 or more deployments ( $73 \%$ vs. $74 \%$ ). Additional details for each unique DS category within demographic categories and across years can be found in Table 2.

\section{Insert Table 4 about here}

Reasons for DS Use

Reasons for use of DSs are presented in Table 5. Among supplement users, reported reasons for use of any DS differed significantly between 2006-07 and 2010-11. Fewer DS users reported using DSs to promote general health $(64 \%$ vs. $58 \%, \mathrm{p}<0.05)$; however, use of DS was reported more often to improve muscle strength $(25 \%$ vs. $30 \%, \mathrm{p}<0.05)$, enhance performance $(17 \%$ vs. $31 \%, p<0.05)$, facilitate weight loss $(12 \%$ vs. $24 \%, \mathrm{p}<0.05)$ and enhance endurance $(8 \%$ vs. $16 \%, \mathrm{p}<0.05)$. For individual DS classes, differences in reasons for use between study periods included an increase in reported use of multivitamins and minerals for weight loss (3\% vs. $8 \%, \mathrm{p}<0.05)$, and individual vitamins and minerals for general health $(55 \%$ vs. $66 \%, \mathrm{p}<0.05)$, to increase energy ( $4 \%$ vs. $12 \%, \mathrm{p}<0.05)$ and improve performance $(3 \%$ vs. $10 \%, \mathrm{p}<0.05)$. Use of individual vitamins and minerals to increase muscle strength decreased between study periods ( $8 \%$ vs. $3 \%, p<0.05)$, as did the use of herbals to facilitate weight loss $(19 \%$ vs. $7 \%, p<0.05)$.

\section{Insert Table 5 about here}




\section{Discussion}

This study observed a significant increase in DS use by Soldiers, from $56 \%$ to $64 \%$, over the 4-year period between 2006-07 and 2010-11 due primarily to the greater use of 3 or more DSs on a weekly basis. Despite increases in DS use by Army personnel, prevalence remained somewhat lower than recent reports of DS use by Air Force (68\%) and Coast Guard (70\%) personnel using a nearly identical survey instrument customized for each military service (Austin et al. 2015; Austin et al. 2016c). Our findings are in contrast to the civilian literature reporting a decrease in DS use (53\% vs. 49\%) during a similar time period (Bailey et al. 2011; Bailey et al. 2013). Increased use of DSs by Soldiers was primarily attributable to a greater use of protein and amino acid products (22\% vs. $26 \%$ ) and combination (10\% vs. $24 \%$ ) products. As with the U.S. civilian population, multivitamin and mineral use did not significantly increase, however, use of individual vitamins and minerals including iron, magnesium, Vitamins A, B-12, and D did increase. Herbal DS use by Soldiers did not increase and remained lower than use by civilians (9\% vs. 20\%, respectively) (Bailey et al. 2011; Bailey et al. 2013).

Increased use of protein and combination DSs by Soldiers is consistent with findings of recent studies of recreational athletes and regular gym users reporting a rise in use of these products (Goston and Correia 2010; Tsitsimpikou et al. 2011). Use of combination products (24\%) by Soldiers is similar to use by Air Force (22\%) and Coast Guard (23\%) personnel (Austin et al. 2015; Austin et al. 2016c). However, protein supplement use was lower (26\%) than the 33\% use observed among Air Force and Coast Guard service members. Similar to the other service branches, prevalence of combination and protein supplement use was significantly associated with increased participation in strength training. These findings are in striking contrast to the general civilian population where use of combination products and protein supplements is 
reported to be only $1 \%$ and $4 \%$, respectively, and is not associated with participation in exercise (Bailey et al. 2011; Bailey et al. 2013). Use of DSs by Soldiers was also significantly more common than reported for college students. Seventeen percent of college students reported the use of protein and amino acid DSs and only 6\% used combination products; however, like military personnel, increased use was associated with participation in exercise programs (Lieberman et al. 2015).

The present study identified demographic and lifestyle characteristics associated with use of DSs by Soldiers. In contrast to the civilian population, protein and combination product use was greater among smokers. This relationship between smoking and DS use was unexpected since studies of civilians and U.S. military personnel have found that increased DS use is associated with an increase in lifestyle behaviors associated with healthy living (Radimer et al. 2004; Austin et al. 2014). However, greater supplement use was associated with smoking among British Army Soldiers in training (Casey et al. 2014). The present study also found that a greater number of young Soldiers (age 18-24 yrs) reported consuming DSs in 2010-11 compared to 2006-07 (62\% vs. 43\%), whereas there were no other differences in prevalence of DS use among other age groups between cohorts. In fact, the differences in DS use for the youngest age group (as well as the least educated and junior enlisted ranks) was largely responsible for the overall increase in DS use that was observed for the 2010-11 cohort. The increased DS use for the youngest age group in the 2010-11 cohort could be largely attributed to their increased use of protein and amino acid, and combination products. It is also of interest to note that DS use appears to be increasing among young active civilians. Prevalence rates of $46 \%$ were observed from a survey conducted in 2007 (Goston and Correia 2010), and use prevalence of 65\% have been reported from surveys conducted more recently on college campuses (Hoyte et al. 2013; 
Lieberman et al. 2015) or local gymnasiums (Lacerda et al. 2015). Thus, the significant difference in DS use among the youngest Soldiers in the present study between the two cohorts could simply reflect the increased DS use, in general, among young active individuals.

Deployment was significantly associated with DS use as indicated by the increased prevalence among those reporting at least one deployment ( $56 \%$ vs. $67 \%)$, confirming previous findings (Jacobson et al. 2012; Austin et al. 2016a). This may reflect the emphasis placed on physical readiness necessary for deployment to a combat theater and the need by Soldiers to participate in regular strength training, a factor that regularly predicts DS use (Goston and Correia 2010). This is consistent with the increased use of protein supplements and combination products by Soldiers performing strength training. Because strength training is often performed to elicit increases in muscle mass, our longitudinal findings of increased participation in strength training and ergogenic supplement use, which purportedly promote increases in lean body mass, are not surprising (Pasiakos et al. 2013).

Reasons cited by Soldiers for use of DSs reflected changes in patterns of use that were observed from cohort to cohort. Promoting general health remained the primary reason for DS use in 2010-11 although compared to 2006-07 fewer respondents reported this reason for use (58\% vs. 64\%, respectively). In 2010-11, Soldiers reported they used DS to improve muscle strength (30\% vs. $25 \%)$, enhance performance (31\% vs. $17 \%)$, increase endurance (16\% vs. $8 \%$ ) and promote weight loss (24\% vs. $12 \%)$, not surprising given their increased use of protein and combination products. The present study is the first to report an increase in use of a multivitamin and mineral to facilitate weight loss (3\% vs. $8 \%)$ and individual vitamins and minerals to improve energy (4\% vs. $11 \%)$ and performance (3\% vs. 10\%). These findings differ significantly from the civilian population where improving health has remained the primary 
reason for use of DSs and few report use of DSs to enhance physical fitness or to promote weight loss (Kaufman et al. 2002; Bailey et al. 2013).

Our findings of increased use of multivitamin and mineral DSs for weight loss purposes may reflect a perceived need to minimize potential micronutrient deficiencies which may occur when Soldiers are participating in popular weight loss programs. Analyses of the nutritional content of several such programs have determined the caloric intake necessary to achieve the recommended weight loss do not provide required levels of micronutrients (Calton 2010). Army personnel are required to meet regulations for body weight and fitness standards to remain in service and be eligible for promotion (Department of Army 2013). With recent reductions in the size of U.S. Armed Forces, personnel may be placing an increased focus on body weight and appearance to improve their ability to compete for promotions and retention in the service. Similarly, the increased use of steroid analogs, which have been purported to increase muscle mass and assist with weight loss, may reflect the desire of Soldiers to retain lean body mass while under energy restriction. Soldiers perform a wide range of physically demanding occupational tasks which can decrease sex steroids (Alemany et al. 2008) and deplete micronutrient stores when under energy restriction (Lukaski 2004). Thus, patterns of DS use may reflect the need to regulate body weight in an occupational field that is physically demanding and requires sustainment of energy levels to perform required job duties.

The increasing prevalence of DS use among Soldiers, especially of performance enhancing supplements, highlights the need for a surveillance system capable of detecting DSs that may be unsafe or cause side effects either alone or in combination. Increased education to ensure appropriate use of DSs by Soldiers is warranted given the extensive use by Soldiers of 
DSs to optimize physical performance and enhance weight loss. Few of the supplements used by Soldiers have been demonstrated to either enhance physical performance or increase weight loss.

\section{Conclusions}

Over the 4-year period between 2006-07 and 2010-11, a relatively brief period of time, supplement use by Soldiers has increased more than 5\% from levels that were already greater than those of the civilian population. The most significant change was in the youngest 18-24 year old Soldiers, consistent with the general increase in DS use noted in the young active civilian population (Hoyte et al. 2013; Lacerda et al. 2015). Like Air Force and Coast Guard personnel, Soldiers use DSs, especially combination products and protein supplements, with the hope these products will enhance performance (Lieberman et al. 2010; Jacobson et al. 2012). Increases in DS use are associated with deployment, participation in aerobic exercise of long duration and strength training (Austin et al. 2016a). The reasons for use of DSs cited by Soldiers indicate increased reliance on performance enhancing products due to the occupational demands faced by Soldiers, such as maintaining and enhancing high levels of physical endurance and strength. Furthermore, Soldiers report relying on DSs to assist with meeting Army occupational requirements for body weight management. Patterns of DS use by Army personnel continue to diverge from that of the civilian population. Understanding cultural factors that influence the use of DSs by Soldiers and other military populations is critical for the development of educational interventions that can reduce unnecessary use of DSs by military and other populations. 


\section{Acknowledgements}

This work was supported by the U.S. Army Medical Research and Materiel Command (USAMRMC) and the Department of Defense Center Alliance for Nutrition and Dietary Supplements Research. The opinions contained herein are the private views of the authors and are not to be construed as official or as reflecting the views of the Army or the Department of Defense. Citations of commercial organizations and trade names in this report do not constitute an official Department of the Army endorsement or approval of the products or services of these organizations. Approved for public release; distribution is unlimited.

T.M. McLellan was supported by the Oak Ridge Institute for Science and Education, as well as through a consulting agreement with the Henry M. Jackson Foundation for the Advancement of Military Medicine Inc.

Contributions of the authors are as follows: HRL designed research; KGA and HRL conducted research; KGA, SGM and LLP analyzed data; KGA, TMM and HRL wrote the paper. The authors would like to thank the United States Army personnel who participated in this study and the healthcare staff for assisting with data collection.

\section{Conflicts of Interest}

The authors have no conflicts of interest to declare.

\section{Funding Disclosure}

This work was supported by the US Army Medical Research and Material Command and the Department of Defense Center Alliance for Nutrition and Dietary Supplement Research. 


\section{References}

Alemany, J.A., Nindl, B.C., Kellogg, M.D., Tharion, W.J., Young, A.J., and Montain, S.J. 2008. Effects of dietary protein content on ICF-1, testosterone, and body composition during 8 days of severe energy deficit and arduous physical activity. J Appl Physiol 105: 58-64.

Austin, K.G., Farina, E.K., and Lieberman, H.R. 2016b. Self-reported side-effects associated with use of dietary supplements in an armed forces population. Drug Test Anal 8: 287-295.

Austin, K.G., McGraw, S.M., and Lieberman, H.R. 2014. Multivitamin and protein supplement use is associated with positive mood states and health behaviors in US military and Coast Guard personnel. J Clin Psychopharm 34: 595-601.

Austin, K.G., McLellan, T.M., Farina, E.K., McGraw, S.M., and Lieberman, H.R. 2016a. Soldier use of dietary supplements, including protein and body building supplements, in a combat zone are different than use in garrison. Appl Physiol Nutr Metab 41: 88-95.

Austin, K.G., Price, L.L., McGraw, S.M., Leahy, G., and Lieberman, H.R. 2016c. Demographic, lifestyle factors and reasons for use of dietary supplements by Air Force personnel. Aerospace Med Hum Perf (accepted for publication).

Austin, K.G., Price, L.L., McGraw, S.M., and Lieberman, H.R. 2015. Predictors of dietary supplement use by U.S. Coast Guard personnel. PLoS One 10: e0133006.

Bailey, R.L., Gahache, J.J., Lentino, C.V., Dwyer, J.T., Engel, J.S., Thomas, P.R., Betz, J.M., Sempos, C.T., and Picciano, M.F. 2011. Dietary supplement use in the United States, 2003-2006. J Nutr 141: 261-266.

Bailey, R.L., Gahche, J.J., Miller, P.E., Thomas, P.R., and Dwyer, J.T. 2013. Why US adults use dietary supplements. JAMA Intern Med 173: 355-361. 
Calton, J.B. 2010. Prevalence of micronutrient deficiency in popular diets. J Int Soc Sports Nutr 7: 24 .

Casey, A., Hughes, J., Izard, R.M., and Greeves, J.P. 2014. Supplement use by UK-based British Army soldiers in training. Br J Nutr 112: 1175-1184.

Denham, B.E. 2011. Dietary supplements - regulatory issues and implications for public health. JAMA 306: 428-429.

Department of Army (1990). Army Regulation AR 70-25. Washington, D.C.: Department of Defense.

Department of Army (2013). Army Regulation AR 600-9. Washington, D.C.: Department of Defense.

Department of Defense (2005). Survey of health related behaviors among active duty military personnel. Washington, D.C.: Department of Defense.

Deuster, P.A. and Lieberman, H.R. 2015. Predicting military personnel from high risk dietary supplements. Drug Test Anal doi: 10.1002/dta.1905 [Epub ahead of print].

Eliason, M.J., Eichner, A., Cancio, A., Bestervelt, L., Adams, B.D., and Deuster, P.A. 2012. Case reports: Death of active duty soldiers following ingestion of dietary supplements containing 1,3-dimethylamylamine (DMAA). Mil Med 177: 1455-1459.

Goston, J.L. and Correia, M.I. 2010. Intake of nutritional supplements among people exercising in gyms and influencing factors. Nutrition 26: 604-611.

Hoyte, C.O., Albert, D., and Heard, K.J. 2013. The use of energy drinks, dietary supplements, and prescription medications by United States college students to enhance athletic performance. J Commun Health 38: 575-580. 
IOM 2008. Institute of Medicine Committee on dietary supplement use by military personnel. Washington, D.C.: National Academy Press.

Jacobson, I.O., Horton, J.L., Smith, B., Wells, T.S., Boyko, E.J., Lieberman, H.R., Ryan, M.A.K., and Smith, T.C. 2012. Bodybuilding, energy, and weight-loss supplements are associated with deployment and physical activity in U.S. military personnel. Ann Epidemiol 22: $318-330$.

Kaufman, D.W., Kelly, J.P., Rosenberg, L., Anderson, T.E., and Mitchell, A.A. 2002. Recent patterns of medication use in the ambulatory adult population of the United States: The Slone Survey. JAMA 287: 337-344.

Lacerda, F.M.M., Carvalho, W.R.G., Hortegal, E.V., Cabral, N.A.L., and Veloso, H.J.F. 2015. Factors associated with dietary supplement use by people who exercise at gyms. Rev Saúde Pública 49: 63.

Lieberman, H.R., Marriott, B.P., Williams, C., Judelson, D.A., Glickman, E.L., Geiselman, P.J., Dotson, L., and Mahoney, C.R. 2015. Patterns of dietary supplement use among college students. Clin Nutr 34: 976-985.

Lieberman, H.R., Stavinoha, T.B., Mcgraw, S.M., White, A., Hadden, L.S., and Marriott, B.P. 2010. Use of dietary supplements among active-duty U.S. Army soldiers. Am J Clin Nutr 92: 985-995.

Lukaski, H.C. 2004. Vitamin and mineral status: effects on physical performance. Nutrition 20: $632-644$.

Pasiakos, S.M., Austin, K.G., Lieberman, H.R., and Askew, E.W. 2013. Efficacy and safety of protein supplements for US Armed Forces personnel: consensus statement. . J Nutr 143: 1811S$1814 \mathrm{~S}$. 
Radimer, K., Bindewald, B., Hughes, J., Ervin, E., Swanson, C., and Picciano, M.F. 2004. Dietary supplement use by US adults: data from the National Health and Nutrition Examination Survey, 1999-2000. Am J Epidemiol 160: 339-349.

Tsitsimpikou, C., Chrisostomou, N., Papalexis, P., Tsarouhas, K., Tsatsakis, A., and Jamurtas, A. 2011. The use of nutritional supplements among recreational athletes in Athens, Greece. Int J Sport Nutr Exerc Metab 21: 377-384. 


\section{Table 1}

Dietary supplement categories derived from the Dietary Supplement and Caffeine Intake Survey of

U.S. Army Active Duty Personnel

\begin{tabular}{|c|c|}
\hline Category & Definition \\
\hline Dietary Supplement & $\begin{array}{l}\text { Any dietary supplement as defined by the Dietary Supplement Health } \\
\text { and Education Act. }\end{array}$ \\
\hline $\begin{array}{l}\text { Multivitamin and } \\
\text { mineral }\end{array}$ & $\begin{array}{l}\text { Dietary supplement containing two or more vitamins or minerals and } \\
\text { no additional supplement ingredients. }\end{array}$ \\
\hline $\begin{array}{l}\text { Individual Vitamins or } \\
\text { Minerals }\end{array}$ & $\begin{array}{l}\text { Dietary supplement that were single nutrient ingredient supplements, } \\
\text { such as calcium or vitamin D. }\end{array}$ \\
\hline Protein and Amino Acid & $\begin{array}{l}\text { Amino acid mixtures, protein powders, and similar products in which } \\
\text { the intention is to provide a single or complex protein source. }\end{array}$ \\
\hline Combination Products & $\begin{array}{l}\text { Dietary supplement with mixtures of ingredients from any of the above } \\
\text { categories; included two or more categories and multiple ingredients. }\end{array}$ \\
\hline $\begin{array}{l}\text { Purported Steroid } \\
\text { Analogs }\end{array}$ & $\begin{array}{c}\text { Steroidal hormones or herbal substitutes for hormones that were } \\
\text { marketed as dietary supplement and included the Supplement Facts } \\
\text { panel on the label. }\end{array}$ \\
\hline Herbal Supplements & $\begin{array}{l}\text { Dietary supplement that included one or more herbal ingredients with } \\
\text { no nutrients or other supplement ingredients; also includes plant- } \\
\text { derived ingredients. }\end{array}$ \\
\hline
\end{tabular}


Table 2 Prevalence $(\% \pm$ SE) of dietary supplement (DS) use within demographic categories and across years for U.S.

Army surveys 2006-7 and 2010-11.

\begin{tabular}{|c|c|c|c|c|c|c|c|c|c|c|c|}
\hline & $\begin{array}{l}\text { Survey } \\
\text { Cohort }\end{array}$ & $\begin{array}{c}\text { Survey } \\
\text { Number }\end{array}$ & $\begin{array}{c}\text { Estimate of } \\
\text { Total Army } \\
\text { Personnel }\end{array}$ & Any DS & $\begin{array}{c}\text { Multivitamin } \\
\text { and } \\
\text { Multimineral }\end{array}$ & $\begin{array}{c}\text { Protein \& } \\
\text { Amino Acid }\end{array}$ & $\begin{array}{c}\text { Individual } \\
\text { Vitamin or } \\
\text { Mineral }\end{array}$ & $\begin{array}{c}\text { Combination } \\
\text { Product }\end{array}$ & Herbal & $\begin{array}{l}\text { Purported } \\
\text { Steroid } \\
\text { Analog }\end{array}$ & Other \\
\hline \multirow[t]{2}{*}{ Characteristic } & $2006-07$ & 989 & 483,882 & $56.1 \pm 1.6$ & $41.2 \pm 1.7$ & $22.2 \pm 1.4$ & $18.6 \pm 1.3$ & $9.9 \pm 1.0$ & $8.5 \pm 0.9$ & $3.0 \pm 0.5$ & $12.7 \pm 1.1$ \\
\hline & $2010-11$ & 1196 & 542,789 & $63.9 \pm 1.7$ & $39.2 \pm 1.7$ & $26.4 \pm 1.5$ & $20.4 \pm 1.4$ & $23.5 \pm 1.4$ & $8.5 \pm 1.0$ & $1.4 \pm 0.3$ & $17.3 \pm 1.3$ \\
\hline \multicolumn{12}{|l|}{ Sex } \\
\hline \multirow[t]{3}{*}{ Male } & & & & $* *$ & & $* *$ & & $* *$ & & $* *$ & * \\
\hline & 2006-07 & 875 & 419,136 & $55.3 \pm 1.7$ & $41.0 \pm 1.8$ & $23.7 \pm 1.5$ & $17.1 \pm 1.3$ & $10.8 \pm 1.1$ & $8.7 \pm 1.0$ & $3.3 \pm 0.6$ & $13.1 \pm 1.2$ \\
\hline & 2010-11 & 1020 & 471,390 & $62.8 \pm 1.9$ & $38.3 \pm 1.9$ & $29.5 \pm 1.6 t$ & $18.3 \pm 1.4$ & $24.5 \pm 1.5 \dagger$ & $8.2 \pm 1.0$ & $1.4 \pm 0.4$ & $17.7 \pm 1.5$ \\
\hline \multirow[t]{3}{*}{ Female } & & & & & & & & $* *$ & & & \\
\hline & 2006-07 & 114 & 64,764 & $61.6+4.7$ & $42.8 \pm 4.9$ & $12.7 \pm 3.6$ & $28.4 \pm 4.5$ & $4.1 \pm 2.2$ & $7.2 \pm 2.8$ & $0.8 \pm 0.8$ & $10.5 \pm 3.0$ \\
\hline & 2010-11 & 176 & 71,399 & $71.4 \pm 3.6$ & $45.7 \pm 4.0$ & $5.8 \pm 1.7$ & $34.2 \pm 3.9 \ddagger$ & $17.1 \pm 2.8$ & $10.3 \pm 2.5$ & $1.29 \pm 0.9$ & $15.2 \pm 2.9$ \\
\hline \multicolumn{12}{|l|}{ Age (Years) } \\
\hline \multirow[t]{3}{*}{18 to 24 Years } & & & & $* *$ & $*$ & $* *$ & & $* *$ & & $*$ & $* *$ \\
\hline & 2006-07 & 393 & 178,383 & $43.0 \pm 2.5$ & $25.7 \pm 2.2$ & $16.1 \pm 1.9$ & $17.0 \pm 1.9$ & $9.3 \pm 1.5$ & $6.4 \pm 1.3$ & $3.8 \pm 1.0$ & $9.8 \pm 1.5$ \\
\hline & 2010-11 & 471 & 169,467 & $62.3 \pm 2.4$ & $32.7 \pm 2.2$ & $33.1 \pm 2.2 \ddagger$ & $21.2 \pm 1.9$ & $27.5 \pm 2.1 \dagger$ & $7.1 \pm 1.2$ & $1.5 \pm 0.6$ & $16.3 \pm 1.8$ \\
\hline \multirow[t]{3}{*}{25 to 29 Years } & & & & & $*$ & & & $* *$ & & & \\
\hline & 2006-07 & 203 & 113,999 & $63.3 \pm 3.5$ & $50.8 \pm 3.7$ & $29.7 \pm 3.5$ & $22.3 \pm 3.2$ & $9.1 \pm 2.1$ & $9.1 \pm 2.2$ & $2.3 \pm 1.0$ & $12.7 \pm 2.4$ \\
\hline & 2010-11 & 361 & 141,367 & $64.3 \pm 2.7$ & $39.1 \pm 2.9$ & $30.7 \pm 2.7 \ddagger$ & $20.0 \pm 2.3$ & $26.4 \pm 2.5 \dagger$ & $8.9 \pm 1.6$ & $1.6 \pm 0.6$ & $15.0 \pm 2.1$ \\
\hline \multirow[t]{3}{*}{30 to 39 Years } & & & & & & & & $*$ & & & \\
\hline & 2006-07 & 234 & 139,275 & $63.9 \pm 3.2$ & $51.1 \pm 3.3$ & $26.3 \pm 3.0$ & $16.9 \pm 2.5$ & $12.8 \pm 2.2$ & $9.8 \pm 1.9$ & $2.9 \pm 1.1$ & $16.0 \pm 2.4$ \\
\hline & 2010-11 & 299 & 161,005 & $64.2 \pm 3.3$ & $41.6 \pm 3.3$ & $20.6 \pm 2.6$ & $21.9 \pm 2.8$ & $20.2 \pm 2.6$ & $9.2 \pm 1.8$ & $1.5 \pm 0.7$ & $21.0 \pm 2.9$ \\
\hline \multicolumn{12}{|l|}{$40+$ Years } \\
\hline & 2006-07 & 159 & 52,225 & $64.8 \pm 3.8$ & $47.2 \pm 4.0$ & $15.7 \pm 3.0$ & $20.1 \pm 3.3$ & $6.6 \pm 2.0$ & $11.1 \pm 2.6$ & $2.1 \pm 1.2$ & $14.1 \pm 2.8$ \\
\hline & 2010-11 & 65 & 70,950 & $66.5 \pm 7.1$ & $49.9 \pm 7.2$ & $14.9 \pm 4.9$ & $15.7 \pm 4.8$ & $15.5 \pm 4.9$ & $9.4 \pm 4.3$ & $0.7 \pm 0.7$ & $16.2 \pm 5.1$ \\
\hline
\end{tabular}

Education 
Some HS/HS

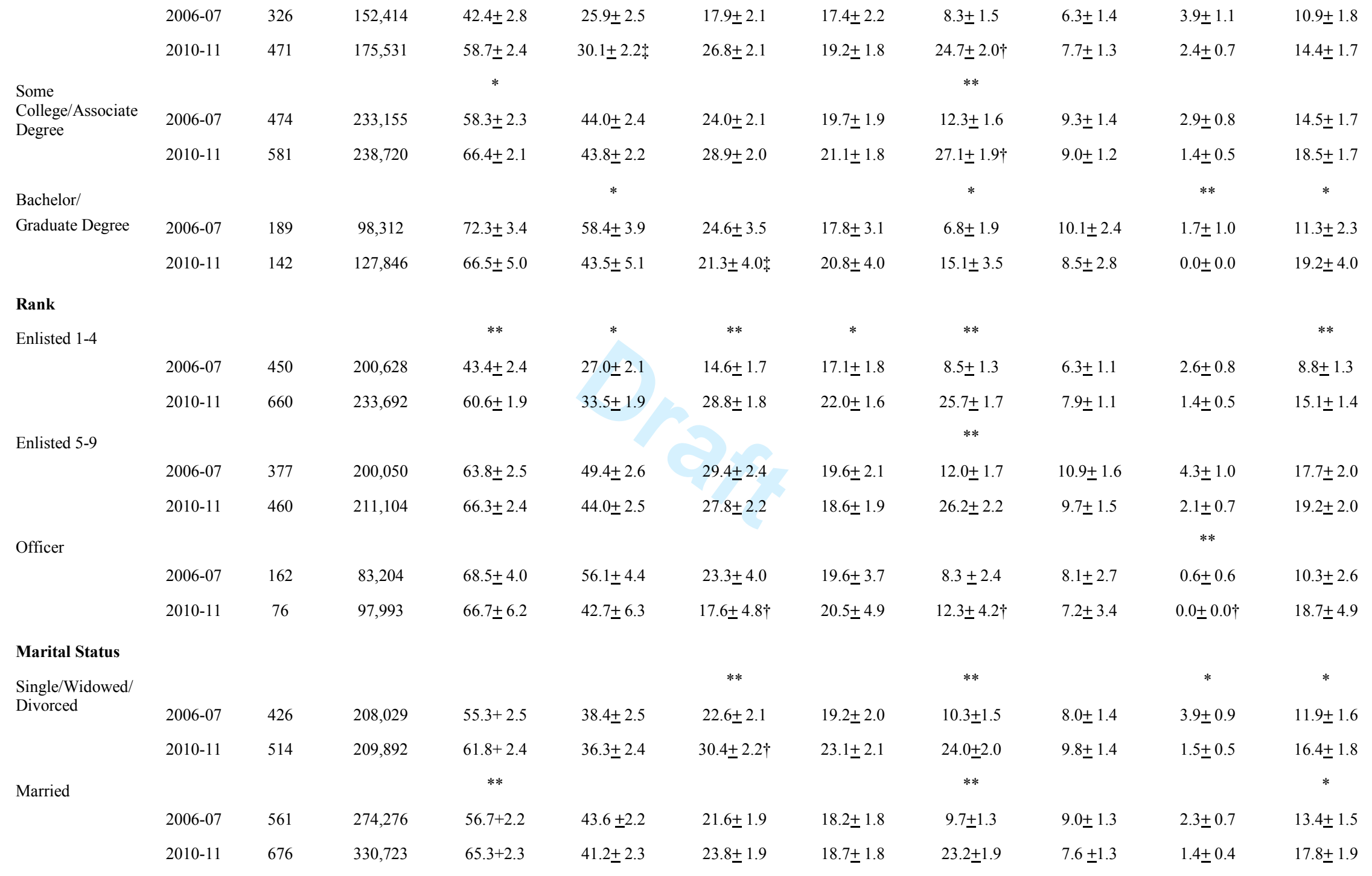

Assignment 
Combat Arms

\begin{tabular}{|c|c|c|c|c|c|c|c|c|c|c|c|}
\hline & 2006-07 & 357 & 174,935 & $61.2 \pm 2.7$ & $47.3 \pm 2.8$ & $30.1 \pm 2.6$ & $19.9 \pm 2.2$ & $13.6 \pm 1.9$ & $8.5 \pm 1.5$ & $4.9 \pm 1.1$ & $14.7 \pm 1.9$ \\
\hline & 2010-11 & 517 & 290,939 & $66.4 \pm 2.6$ & $35.2 \pm 2.4$ & $38.7 \pm 2.5$ & $19.2 \pm 2.0$ & $28.4 \pm 2.3$ & $9.9 \pm 1.7$ & $2.2 \pm 0.6 \dagger$ & $20.5 \pm 2.3$ \\
\hline \multirow[t]{3}{*}{ Combat Support } & & & & $*$ & & & & $* *$ & & & $* *$ \\
\hline & $2006-07$ & 309 & 148,897 & $52.5 \pm 3.0$ & $37.9 \pm 2.9$ & $20.5 \pm 2.5$ & $16.6 \pm 2.2$ & $8.3 \pm 1.7$ & $9.1 \pm 1.7$ & $2.6 \pm 0.9$ & $10.4 \pm 1.8$ \\
\hline & 2010-11 & 191 & 86,451 & $65.6 \pm 3.8$ & $43.9 \pm 4.3$ & $24.9 \pm 3.9$ & $19.6 \pm 3.4$ & $27.0 \pm 3.8$ & $11.3 \pm 2.6$ & $0.9 \pm 0.7$ & $23.5 \pm 3.7$ \\
\hline \multirow{3}{*}{$\begin{array}{l}\text { Combat Service } \\
\text { Support }\end{array}$} & & & & & & & & $* *$ & & & \\
\hline & 2006-07 & 315 & 155,840 & $54.4 \pm 2.9$ & $37.8 \pm 2.9$ & $15.5 \pm 2.3$ & $19.0 \pm 2.4$ & $7.6 \pm 1.5$ & $8.2 \pm 1.7$ & $1.3 \pm 0.7$ & $13.1 \pm 2.0$ \\
\hline & 2010-11 & 479 & 221,227 & $60.4 \pm 2.8 \dagger$ & $41.1 \pm 2.8$ & $14.7 \pm 1.7$ & $21.9 \pm 2.2$ & $17.0 \pm 1.8 \ddagger$ & $6.0 \pm 1.2 \%$ & $0.8 \pm 0.4$ & $11.8 \pm 1.6 \ddagger$ \\
\hline \multicolumn{12}{|l|}{ Tobacco Use } \\
\hline \multirow[t]{3}{*}{ Currently Use } & & & & $* *$ & & $* *$ & & $* *$ & & & $* *$ \\
\hline & 2006-07 & 422 & 203,522 & $48.9 \pm 2.5$ & $33.3 \pm 2.4$ & $19.8 \pm 2.1$ & $14.8 \pm 1.8$ & $9.9 \pm 1.5$ & $5.8 \pm 1.2$ & $4.0 \pm 1.0$ & $11.5 \pm 1.6$ \\
\hline & 2010-11 & 547 & 230,986 & $63.3 \pm 2.3$ & $37.5 \pm 2.4$ & $30.0 \pm 2.2$ & $18.6 \pm 1.9$ & $28.4 \pm 2.1$ & $8.2 \pm 1.3$ & $1.8 \pm 0.6$ & $18.9 \pm 2.1$ \\
\hline \multirow[t]{3}{*}{ Formerly Used } & & & & & $*$ & & & $* *$ & & & \\
\hline & 2006-07 & 177 & 84,956 & $62.5 \pm 3.8$ & $49.5 \pm 3.9$ & $24.7 \pm 3.4$ & $23.3 \pm 3.4$ & $8.9 \pm 2.3$ & $11.7 \pm 2.6$ & $3.3 \pm 1.3$ & $15.9 \pm 2.8$ \\
\hline & 2010-11 & 223 & 102,228 & $70.5 \pm 4.0$ & $39.9 \pm 4.0$ & $31.9 \pm 3.8$ & $24.1 \pm 3.4$ & $26.6 \pm 3.6$ & $10.1 \pm 2.0$ & $2.4 \pm 1.0$ & $19.3 \pm 2.9$ \\
\hline \multirow[t]{3}{*}{ Never Used } & & & & & & & & $*$ & & & \\
\hline & 2006-07 & 385 & 192,608 & $60.9 \pm 2.6$ & $46.3 \pm 2.7$ & $23.3 \pm 2.3$ & $20.7 \pm 2.2$ & $10.6 \pm 1.7$ & $10.1 \pm 1.6$ & $1.9 \pm 0.7$ & $12.6 \pm 1.8$ \\
\hline & $2010-11$ & 420 & 207,067 & $61.5 \pm 3.0$ & $40.8 \pm 3.0$ & $19.8 \pm 2.1 \ddagger$ & $20.8 \pm 2.3$ & $16.7 \pm 2.0 \$$ & $8.0 \pm 1.8$ & $0.5 \pm 0.3$ & $14.8 \pm 2.2$ \\
\hline \multicolumn{12}{|l|}{ Deployed } \\
\hline \multirow[t]{3}{*}{ Non-Deployed } & & & & & & * & & $* *$ & & & $*$ \\
\hline & 2006-07 & 328 & 153,476 & $48.5 \pm 2.9$ & $34.8 \pm 2.8$ & $14.9 \pm 2.1$ & $20.4 \pm 2.3$ & $9.1 \pm 1.7$ & $5.5 \pm 1.4$ & $2.8 \pm 0.9$ & $8.4 \pm 1.5$ \\
\hline & 2010-11 & 308 & 128,614 & $55.6 \pm 3.3$ & $32.9 \pm 3.0 \dagger$ & $20.7 \pm 2.6 \dagger$ & $22.8 \pm 2.6$ & $16.5 \pm 2.2 \ddagger$ & $6.5 \pm 1.5$ & $1.6 \pm 0.7$ & $13.1 \pm 2.0$ \\
\hline \multirow[t]{3}{*}{ Deployed } & & & & $* *$ & & & & $* *$ & & $*$ & \\
\hline & 2006-07 & 651 & 325,888 & $59.8 \pm 2.0$ & $44.5 \pm 2.1$ & $25.5 \pm 1.8$ & $17.7 \pm 1.6$ & $10.5 \pm 1.2$ & $9.8 \pm 1.2$ & $3.1 \pm 0.7$ & $14.9 \pm 1.5$ \\
\hline & 2010-11 & 876 & 409,645 & $66.5 \pm 2.0 \ddagger$ & $41.2 \pm 2.0$ & $28.3 \pm 1.7$ & $19.6 \pm 1.6$ & $25.8 \pm 1.7$ & $9.0 \pm 1.2$ & $1.4 \pm 0.4$ & $18.5 \pm 1.6$ \\
\hline
\end{tabular}




\begin{tabular}{|c|c|c|c|c|c|c|c|c|c|c|c|}
\hline \multirow[t]{3}{*}{ None } & & & & & & $*$ & & ** & & & * \\
\hline & $2006-07$ & 328 & 153,476 & $48.5 \pm 2.9$ & $34.8 \pm 2.8$ & $14.9 \pm 2.1$ & $20.4 \pm 2.3$ & $9.1 \pm 1.7$ & $5.5 \pm 1.4$ & $2.8 \pm 0.9$ & $8.4 \pm 1.52$ \\
\hline & 2010-11 & 308 & 128,614 & $55.6 \pm 3.3$ & $32.9 \pm 3.0$ & $20.7 \pm 2.6 \dagger$ & $22.8 \pm 2.6$ & $16.5 \pm 2.2$ & $6.5 \pm 1.5$ & $1.6 \pm 0.7$ & $13.1 \pm 2.0$ \\
\hline \multirow[t]{3}{*}{$1-2$} & & & & $* *$ & & & & ** & & * & * \\
\hline & $2006-07$ & 512 & 257,844 & $56.7 \pm 2.3$ & $40.7 \pm 2.3$ & $23.6 \pm 2.0$ & $16.7 \pm 1.8$ & $8.9 \pm 1.3$ & $9.6 \pm 1.4$ & $3.2 \pm 0.8$ & $13.6 \pm 1.6$ \\
\hline & 2010-11 & 631 & 284,545 & $67.9 \pm 2.2$ & $42.3 \pm 2.4$ & $26.9 \pm 2.1$ & $21.2 \pm 1.9$ & $26.0 \pm 2.0$ & $9.1 \pm 1.5$ & $1.1 \pm 0.4$ & $19.0 \pm 2.0$ \\
\hline \multirow[t]{3}{*}{$3-4$} & & & & & $* *$ & & & * & & & \\
\hline & $2006-07$ & 97 & 47,228 & $71.3 \pm 4.8$ & $59.1 \pm 5.2$ & $31.2 \pm 4.9$ & $24.8 \pm 4.6$ & $14.3 \pm 3.7$ & $11.1 \pm 3.2$ & $2.0 \pm 1.4$ & $18.4 \pm 4.0$ \\
\hline & 2010-11 & 199 & 100,291 & $60.8 \pm 4.4$ & $37.5 \pm 4.1$ & $31.3 \pm 3.5$ & $15.7 \pm 3.3$ & $27.5 \pm 3.5$ & $8.7 \pm 2.0$ & $2.5 \pm 1.0$ & $14.8 \pm 2.6$ \\
\hline \multirow[t]{3}{*}{$5+$} & & & & & & & & & & $* *$ & \\
\hline & 2006-07 & 42 & 20,816 & $72.5 \pm 7.1$ & $57.7 \pm 7.9$ & $36.4 \pm 8.0$ & $14.1 \pm 5.5$ & $20.9 \pm 6.4$ & $8.6 \pm 4.3$ & $4.6 \pm 3.2$ & $24.2 \pm 7.1$ \\
\hline & $2010-11$ & 46 & 24,809 & $73.9 \pm 7.7$ & $43.7 \pm 8.8$ & $33.5 \pm 8.1$ & $16.7 \pm 7.0$ & $16.7 \pm 5.3$ & $9.3 \pm 4.9$ & $0.0 \pm 0.0$ & $27.6 \pm 7.8$ \\
\hline \multicolumn{12}{|c|}{$\begin{array}{l}\text { Body Mass } \\
\text { Index }\left(\mathrm{kg} / \mathrm{m}^{2}\right)\end{array}$} \\
\hline \multirow{3}{*}{18.5 to 24.9} & & & & * & & $* *$ & & $* *$ & & & \\
\hline & 2006-07 & 340 & 165,747 & $47.6 \pm 2.8$ & $34.1 \pm 2.7$ & $16.5 \pm 2.2$ & $17.1 \pm 2.2$ & $7.7 \pm 1.6$ & $4.6 \pm 1.3$ & $3.5 \pm 1.0$ & $11.5 \pm 1.8$ \\
\hline & 2010-11 & 294 & 128,231 & $58.1 \pm 3.4$ & $30.6 \pm 3.1$ & $27.0 \pm 2.7$ & $20.3 \pm 2.6$ & $17.7 \pm 2.2$ & $6.7 \pm 1.5$ & $1.6 \pm 0.7$ & $15.7 \pm 2.2$ \\
\hline \multirow[t]{3}{*}{25 to 29.9} & & & & & & $* *$ & & ** & & & * \\
\hline & $2006-07$ & 502 & 245,884 & $58.3 \pm 2.3$ & $43.1 \pm 2.3$ & $23.6 \pm 2.0$ & $19.0 \pm 1.8$ & $9.4 \pm 1.3$ & $10.1 \pm 1.4$ & $2.8 \pm 0.7$ & $12.4 \pm 1.5$ \\
\hline & $2010-11$ & 507 & 237,811 & $65.0 \pm 2.7 \dagger$ & $41.7 \pm 2.7 \%$ & $30.0 \pm 2.4$ & $21.8 \pm 2.4$ & $24.0 \pm 2.1$ & $8.9 \pm 1.4$ & $1.7 \pm 0.5$ & $17.1 \pm 1.9$ \\
\hline \multirow[t]{3}{*}{$30+$} & & & & & & & & * & & & \\
\hline & 2006-07 & 132 & 64,609 & $67.4 \pm 4.1$ & $52.4 \pm 4.5$ & $31.0 \pm 4.2$ & $18.1 \pm 3.6$ & $17.3 \pm 3.5$ & $12.1 \pm 3.0$ & $2.2 \pm 1.3$ & $17.0 \pm 3.4$ \\
\hline & $2010-11$ & 376 & 169,772 & $66.8 \pm 2.8$ & $42.9 \pm 3.1$ & $21.6 \pm 2.5$ & $17.9 \pm 2.3$ & $27.3 \pm 2.8 \dagger$ & $9.0 \pm 1.9$ & $0.9 \pm 0.5$ & $18.9 \pm 2.8$ \\
\hline \multicolumn{12}{|c|}{$\begin{array}{l}\text { Weekly Aerobic } \\
\text { Exercise (min) }\end{array}$} \\
\hline \multirow[t]{3}{*}{0 to 60} & & & & & & & & & & N/A & \\
\hline & $2006-07$ & 66 & 31,382 & $48.0 \pm 6.5$ & $36.2 \pm 6.4$ & $11.7 \pm 4.3$ & $13.9 \pm 4.3$ & $4.0 \pm 2.9$ & $4.3 \pm 2.2$ & $0.0 \pm 0.0$ & $10.7 \pm 4.0$ \\
\hline & 2010-11 & 44 & 36,617 & $41.7 \pm 9.8 \dagger$ & $16.1 \pm 7.5 \dagger$ & $16.4 \pm 8.4$ & $24.4 \pm 8.1$ & $6.4 \pm 3.32$ & $6.8 \pm 3.5$ & $0.0 \pm 0.0$ & $23.7 \pm 8.7$ \\
\hline
\end{tabular}




\begin{tabular}{|c|c|c|c|c|c|c|c|c|c|c|c|}
\hline & 2006-07 & 416 & 199,623 & $54.8 \pm 2.6$ & $40.1 \pm 2.5$ & $17.9 \pm 2.1$ & $18.3 \pm 2.0$ & $7.2 \pm 1.3$ & $7.2 \pm 1.4$ & $1.3 \pm 0.6$ & $12.0 \pm 1.6$ \\
\hline & 2010-11 & 477 & 233,785 & $55.1 \pm 5.5$ & $40.5 \pm 5.4$ & $16.1 \pm 3.4$ & $19.2 \pm 4.2$ & $13.4 \pm 2.8 \ddagger$ & $6.9 \pm 2.2$ & $2.8 \pm 1.3$ & $9.7 \pm 2.6$ \\
\hline \multirow{4}{*}{315 to 464} & & & & & & & & $* *$ & & & \\
\hline & 2006-07 & 256 & 125,919 & $55.8 \pm 3.2$ & $40.4 \pm 3.2$ & $23.9 \pm 2.8$ & $18.6 \pm 2.5$ & $11.8 \pm 2.2$ & $8.9 \pm 1.8$ & $3.2 \pm 1.1$ & $13.2 \pm 2.2$ \\
\hline & 2010-11 & 321 & 138,595 & $62.1 \pm 4.3$ & $36.6 \pm 4.1$ & $21.5 \pm 3.5$ & $14.7 \pm 2.8$ & $23.6 \pm 3.7$ & $6.9 \pm 1.8$ & $1.2 \pm 0.7$ & $13.1 \pm 2.5$ \\
\hline & & & & * & & & & $* *$ & & $* *$ & \\
\hline \multirow[t]{2}{*}{$465+$} & 2006-07 & 242 & 122,659 & $60.2 \pm 3.2$ & $45.3 \pm 3.3$ & $30.8 \pm 3.1$ & $19.3 \pm 2.7$ & $14.2 \pm 2.3$ & $11.7 \pm 2.2$ & $6.4 \pm 1.6$ & $14.2 \pm 2.3$ \\
\hline & 2010-11 & 328 & 131,352 & $67.8 \pm 1.9$ & $41.3 \pm 2.0$ & $31.1 \pm 1.8 \neq$ & $22.4 \pm 1.7$ & $27.0 \pm 1.7$ & $9.5 \pm 1.3$ & $1.29 \pm 0.4$ & $19.9 \pm 1.8$ \\
\hline \multicolumn{12}{|c|}{$\begin{array}{l}\text { Weekly Strength } \\
\text { Training }\end{array}$} \\
\hline & & & & $* *$ & & $* *$ & & $* *$ & & & $*$ \\
\hline \multirow[t]{3}{*}{ No } & 2006-07 & 252 & 122,669 & $33.6 \pm 3.1$ & $21.4 \pm 2.8$ & $4.6 \pm 1.5$ & $16.8 \pm 2.5$ & $3.8 \pm 1.2$ & $4.7 \pm 1.5$ & $0.4 \pm 0.4$ & $6.2 \pm 1.6$ \\
\hline & 2010-11 & 257 & 115,949 & $49.9 \pm 3.8 \ddagger$ & $28.6 \pm 3.4 \ddagger$ & $11.0 \pm 2.0$ & $20.4 \pm 2.8$ & $10.4 \pm 2.0$ & $5.6 \pm 1.5$ & $1.7 \pm 0.8$ & $11.3 \pm 1.9$ \\
\hline & & & & & & & & $* *$ & & $* *$ & * \\
\hline \multirow[t]{2}{*}{ Yes } & 2006-07 & 729 & 357,180 & $63.7 \pm 1.8$ & $48.1 \pm 1.9$ & $28.5 \pm 1.8$ & $18.9 \pm 1.5$ & $12.2 \pm 1.3$ & $9.9 \pm 1.2$ & $3.9 \pm 0.7$ & $15.1 \pm 1.4$ \\
\hline & 2010-11 & 933 & 424,401 & $67.8 \pm 1.8$ & $42.2 \pm 2.0$ & $30.7 \pm 1.7 \ddagger$ & $20.5 \pm 1.6$ & $27.1 \pm 1.7 \ddagger$ & $9.3 \pm 1.1$ & $1.3 \pm 0.4$ & $19.1 \pm 1.6 \ddagger$ \\
\hline
\end{tabular}

$*=\mathrm{p}<0.05 ; * *=\mathrm{p}<0.01$ for comparisons between 2006-07 and 2010-11 cohorts. $\dagger=\mathrm{p}<0.05 ; \uparrow=\mathrm{p}<0.01$ for comparisons within 2010-11 cohort. 
Table 3 Comparison of U.S. Army surveys 2006-07 and 2010-11 top individual vitamins and minerals reported to be used at least once per week over the six months prior to the survey.

\begin{tabular}{lccc}
\hline Individual Vitamin or Mineral & $\mathbf{2 0 0 6 - 0 7}$ & $\mathbf{2 0 1 0 - 1 1}$ & \\
\hline Vitamin C & $\mathbf{S E}$ & $\mathbf{\%} \pm \mathbf{S E}$ & p-value \\
Calcium & $12.8 \pm 1.1$ & $13.3 \pm 1.1$ & 0.78 \\
Vitamin D & $8.3 \pm 0.9$ & $10.3 \pm 1.0$ & 0.14 \\
Vitamin E & $6.3 \pm 0.8$ & $10.3 \pm 1.0$ & 0.002 \\
Vitamin A & $6.9 \pm 0.9$ & $9.1 \pm 1.0$ & 0.10 \\
Iron & $5.5 \pm 0.8$ & $8.1 \pm 0.9$ & 0.03 \\
Zinc & $4.6 \pm 0.7$ & $7.1 \pm 0.9$ & 0.03 \\
Vitamin B6 & $3.8 \pm 0.6$ & $5.4 \pm 0.9$ & 0.13 \\
Vitamin B12 & $3.2 \pm 0.7$ & $4.6 \pm 0.8$ & 0.15 \\
Folate & $3.7 \pm 0.6$ & $6.2 \pm 0.8$ & 0.01 \\
Magnesium & $3.7 \pm 0.7$ & $5.0 \pm 0.8$ & 0.21 \\
Selenium & $3.4 \pm 0.6$ & $6.1 \pm 0.9$ & 0.01 \\
\hline
\end{tabular}


Table 4 Comparison of U.S. Army surveys 2006-07 and 2010-11 association of number and type of dietary supplement (DS) use at least once per week over the previous six months by supplement ingredients with selected demographic and lifestyle characteristics. Significance values are presented based on logistic regression modeling, adjusted for age, sex and rank.

\begin{tabular}{|c|c|c|c|c|c|c|c|c|}
\hline \multicolumn{9}{|c|}{ Dietary Supplements Taken at Least Once a Week } \\
\hline & Any DS & $\begin{array}{l}\text { Multivitamin } \\
\text { and } \\
\text { Multimineral }\end{array}$ & $\begin{array}{c}\text { Protein \& } \\
\text { Amino } \\
\text { Acid } \\
\end{array}$ & $\begin{array}{c}\text { Individual } \\
\text { Vitamin or } \\
\text { Mineral } \\
\end{array}$ & $\begin{array}{l}\text { Combination } \\
\text { Product }\end{array}$ & Herbal & $\begin{array}{c}\text { Purported } \\
\text { Steroid } \\
\text { Analog } \\
\end{array}$ & Other \\
\hline Sex & 0.65 & 0.41 & 0.01 & 0.56 & 0.32 & 0.40 & 0.28 & 0.88 \\
\hline Age (Years) & 0.002 & 0.002 & $<0.0001$ & 0.28 & 0.10 & 0.96 & 0.88 & 0.63 \\
\hline Education & 0.02 & 0.045 & 0.17 & 0.94 & 0.50 & 0.77 & $<0.0001$ & 0.57 \\
\hline Rank & 0.005 & 0.008 & $<0.0001$ & 0.31 & 0.18 & 0.57 & $<0.0001$ & 0.12 \\
\hline Occupation & 0.60 & 0.01 & 0.29 & 0.60 & 0.32 & 0.32 & 0.85 & 0.01 \\
\hline Deployed & 0.76 & 0.97 & 0.31 & 0.80 & 0.19 & 0.51 & 0.64 & 0.40 \\
\hline Deployment Tours & 0.03 & 0.03 & 0.41 & 0.17 & 0.02 & 0.89 & $<0.0001$ & 0.27 \\
\hline Marital Status & 0.49 & 0.87 & 0.17 & 0.53 & 0.98 & 0.24 & 0.48 & 0.87 \\
\hline BMI $\left(\mathrm{kg} / \mathrm{m}^{2}\right)$ & 0.55 & 0.64 & 0.005 & 0.80 & 0.28 & 0.39 & 0.88 & 0.87 \\
\hline Tobacco Use & 0.04 & 0.06 & 0.02 & 0.56 & 0.04 & 0.27 & 0.64 & 0.43 \\
\hline Aerobic Exercise Duration & 0.49 & 0.42 & 0.97 & 0.22 & 0.94 & 0.77 & 0.003 & 0.18 \\
\hline Strength Training & 0.07 & 0.04 & 0.04 & 0.57 & 0.79 & 0.65 & 0.02 & 0.38 \\
\hline
\end{tabular}


Table 5 Comparison of U.S. Army surveys 2006-07 and 2010-11 reported reasons $(\% \pm$ SE) for using any dietary supplement (DS) and specific DS types at least once per week over the six months prior to the survey.

\begin{tabular}{|c|c|c|c|c|c|c|c|c|c|}
\hline $\begin{array}{c}\text { Reported } \\
\text { Reasons for } \\
\text { DS Use } \\
\end{array}$ & Survey & Any DS & $\begin{array}{l}\text { Multivitamin } \\
\text { or } \\
\text { Multimineral } \\
\end{array}$ & $\begin{array}{c}\text { Protein \& } \\
\text { Amino Acid }\end{array}$ & $\begin{array}{c}\text { Individual } \\
\text { Vitamin or } \\
\text { Mineral } \\
\end{array}$ & $\begin{array}{c}\text { Combination } \\
\text { Product }\end{array}$ & Herbal & $\begin{array}{c}\text { Purported } \\
\text { Steroid } \\
\text { Analog } \\
\end{array}$ & Other \\
\hline \multirow[t]{2}{*}{$\begin{array}{c}\text { Promote } \\
\text { general health }\end{array}$} & $2006-07$ & $\begin{array}{c}64.2 \pm 2.1 \\
*\end{array}$ & $76.1 \pm 2.2$ & $20.9 \pm 2.8$ & $\begin{array}{c}55.2 \pm 3.7 \\
*\end{array}$ & $18.8 \pm 4.0$ & $34.5 \pm 5.3$ & $16.8 \pm 6.9$ & $35.7 \pm 4.3$ \\
\hline & 2010-11 & 58.01 .8 & $73.2 \pm 2.4$ & $23.4 \pm 2.7$ & $65.7 \pm 3.3$ & $11.9 \pm 1.8$ & $35.6 \pm 5.7$ & $22.0 \pm 10.0$ & $39.4 \pm 4.3$ \\
\hline \multirow[t]{2}{*}{$\begin{array}{l}\text { Give more } \\
\text { energy }\end{array}$} & 2006-07 & $31.1 \pm 2.0$ & $8.9 \pm 1.5$ & $11.2 \pm 2.2$ & $\begin{array}{c}4.4 \pm 1.5 \\
*\end{array}$ & $16.4 \pm 3.8$ & $15.6 \pm 4.0$ & $11.8 \pm 6.0$ & $22.7 \pm 3.7$ \\
\hline & 2010-11 & $27.9 \pm 1.6$ & $8.1 \pm 1.3$ & $7.5 \pm 1.6$ & $11.8 \pm 2.3$ & $23.1 \pm 2.7$ & $14.6 \pm 4.3$ & $15.5 \pm 8.5$ & $32.4 \pm 4.1$ \\
\hline \multirow{2}{*}{$\begin{array}{l}\text { Greater } \\
\text { muscle } \\
\text { strength }\end{array}$} & 2006-07 & $\begin{array}{c}24.9 \pm 1.9 \\
*\end{array}$ & $7.7 \pm 1.4$ & $59.0 \pm 3.4$ & $\begin{array}{c}8.3 \pm 2.1 \\
*\end{array}$ & $37.9 \pm 5.0$ & $11.2 \pm 3.5$ & $49.3 \pm 9.3$ & $7.8 \pm 2.4$ \\
\hline & 2010-11 & $30.2 \pm 1.7$ & $5.2 \pm 1.1$ & $53.5 \pm 3.1$ & $2.8 \pm 1.3$ & $27.1 \pm 2.8$ & $9.3 \pm 2.8$ & $45.0 \pm 11.5$ & $3.4 \pm 1.2$ \\
\hline \multirow[t]{2}{*}{$\begin{array}{c}\text { Performance } \\
\text { enhancer }\end{array}$} & 2006-07 & $\begin{array}{c}16.7 \pm 1.6 \\
*\end{array}$ & $8.1 \pm 1.4$ & $30.4 \pm 3.2$ & $\begin{array}{c}3.0 \pm 1.3 \\
*\end{array}$ & $31.1 \pm 4.8$ & $11.9 \pm 3.6$ & $48.1 \pm 9.3$ & $\begin{array}{c}4.5 \pm 3.2 \\
*\end{array}$ \\
\hline & 2010-11 & 30.61 .7 & $9.2 \pm 1.4$ & $30.1 \pm 2.8$ & $9.6 \pm 2.1$ & $36.2 \pm 3.1$ & $17.8 \pm 4.3$ & $31.8 \pm 11.1$ & $4.0 \pm 3.2$ \\
\hline \multirow[t]{2}{*}{ Weight loss } & 2006-07 & $\begin{array}{c}12.4 \pm 1.4 \\
*\end{array}$ & $\begin{array}{c}2.7 \pm 0.8 \\
*\end{array}$ & $9.2 \pm 2.0$ & $4.5 \pm 1.6$ & $39.9 \pm 5.0$ & $\begin{array}{c}19.0 \pm 4.3 \\
*\end{array}$ & $0.0 \pm 0.0$ & $\begin{array}{c}0.4 \pm 2.7 \\
*\end{array}$ \\
\hline & 2010-11 & $23.7 \pm 1.5$ & $8.4 \pm 1.5$ & $9.9 \pm 2.3$ & $6.3 \pm 1.5$ & $37.5 \pm 3.2$ & $7.1 \pm 2.5$ & $9.1 \pm 6.4$ & $2.4 \pm 3.01$ \\
\hline \multirow[t]{2}{*}{$\begin{array}{l}\text { Increased } \\
\text { endurance }\end{array}$} & 2006-07 & $\begin{array}{c}8.1 \pm 1.2 \\
*\end{array}$ & $2.9 \pm 0.9$ & $11.0 \pm 2.2$ & $1.2 \pm 0.8$ & $11.6 \pm 3.3$ & $8.3 \pm 3.1$ & $17.7 \pm 7.1$ & $3.4 \pm 1.6$ \\
\hline & 2010-11 & 16.41 .4 & $5.5 \pm 1.4$ & $12.7 \pm 2.1$ & $2.3 \pm 0.9$ & $18.5 \pm 2.3$ & $7.2 \pm 2.4$ & $4.8 \pm 4.8$ & $4.0 \pm 1.7$ \\
\hline Not sure & $\begin{array}{l}2006-07 \\
2010-11\end{array}$ & $\begin{array}{l}6.9 \pm 1.1 \\
7.8 \pm 1.0\end{array}$ & $\begin{array}{l}3.6 \pm 1.0 \\
2.1 \pm 0.6\end{array}$ & $\begin{array}{l}2.1 \pm 1.0 \\
1.5 \pm 0.6\end{array}$ & $\begin{array}{l}8.6 \pm 2.1 \\
6.6 \pm 1.5\end{array}$ & $\begin{array}{l}1.5 \pm 1.2 \\
1.2 \pm 0.6\end{array}$ & $\begin{array}{l}3.5 \pm 2.0 \\
8.0 \pm 2.6\end{array}$ & $\begin{array}{l}0.0 \pm 0.0 \\
4.7 \pm 4.8\end{array}$ & $\begin{array}{l}8.7 \pm 2.5 \\
5.9 \pm 1.6\end{array}$ \\
\hline Other & $\begin{array}{l}2006-07 \\
2010-11\end{array}$ & $\begin{array}{l}11.8 \pm 1.4 \\
13.0 \pm 1.2\end{array}$ & $\begin{array}{l}3.7 \pm 1.0 \\
1.9 \pm 0.7\end{array}$ & $\begin{array}{l}4.6 \pm 1.5 \\
3.8 \pm 1.0\end{array}$ & $\begin{array}{l}9.8 \pm 2.2 \\
7.0 \pm 1.9\end{array}$ & $\begin{array}{l}1.4 \pm 1.2 \\
1.9 \pm 0.8\end{array}$ & $\begin{array}{c}9.3 \pm 3.2 \\
13.1 \pm 3.6\end{array}$ & $\begin{array}{l}3.6 \pm 3.4 \\
5.1 \pm 5.1\end{array}$ & $\begin{array}{c}16.4 \pm 3.3 \\
9.5 \pm 2.2\end{array}$ \\
\hline
\end{tabular}

* significant difference between surveys, $\mathrm{p}<0.05$ 